\title{
KEWENANGAN MAHKAMAH KONSTITUSI DALAM MENGADILI PERKARA PERSELISIHAN HASIL PEMILIHAN KEPALA DAERAH (SUATU KAJIAN TERHADAP PUTUSAN MAHKAMAH KONSTITUSI NOMOR 97/PUU-XI/2013 JO. PUTUSAN MAHKAMAH KONSTITUSI NOMOR 072-073/PUU-II/2004)
}

\author{
Hardy Salim \\ (Mahasiswa Program S1 Fakultas Hukum Universitas Tarumanagara) \\ (E-mail: hardys197@gmail.com)

\section{Dr. Cut Memi, S.H., M.H.} \\ (Corresponding Author) \\ (Dosen Fakultas Hukum Universitas Tarumanagara. Meraih Sarjana Hukum pada Fakultas Hukum \\ Universitas Andalas, Magister Hukum pada Fakultas Hukum Universitas Tarumanagara, Doktor (Dr.) \\ pada Fakultas Hukum Universitas Katolik Parahyangan) \\ (E-mail: cutm@fh.untar.ac.id)
}

\begin{abstract}
Acccording to the Arrticle 24C paragaaph (1) the Constttution of thr Republic of Indonesia of 1945, the Constitutional Court of thr Republic of Indonesia have thr power to decide upon disputes over the results of general election. The general election referred to here is elections to elect members of the legislature, regional representative councils, regional legislatures, president amd vice president. Both of thr provisions have been limitative, so there will no be any other elections that included. However, in its development, the Constittutional Court of the Republc of Indonesia is given the power to decide upon disputes ovrr the results of regional hed elections with a legal basis of the Constittutional Court Ruling Number 072-073/PUU-II/2004. However, a litle later the Constttution Court of the Republic of Indonesia issued a Consttttuional Court Ruling Number 97/PUU-XI/2013 which said tht the Constitusional Court of the Republic of Indonesia can't have the power to decide upon disputes over the resuls of regional hed elections. This reaises problems regarding whether regional head elections are included in thr general election regime? And whether the Constitutional Court of the Republic Indonesia has thr authorty to decide upon disputes over the results of regional hed elections? Thr Author examined the issue by normative method. The results of thr resrarch show tht thr regional hesd elections is not a part of the general electiins regime and the Constututional Corrt of the Republic Indonesia can't have thr power to decide upon disputes ovrr thr resulls of the regional hesd elections.
\end{abstract}

Keywords: Authority, tbe Constituional Court of the Republic of Indonesia, Regional Head Elections. 


\section{PENDAHULUAN}

\section{A. Latar Belakang}

Dalam upaya penegakkan hokum serta keadilan di Indonesia, terdapat beberapa lembagga negara yang melaksanakan kekuasaan kehakiman yang merdeka untuk melaksanakan sautu pengadilan, yang salah satunya adalah Mahkamah Konstitusi, sebagaimana dikemukakan dalam Pasal 24 ayat (2) Undang-Undang Dasar Negara Republik Indonesia Tahun 1945 (yang selanjjutnya disebut dengan UUD NRI 1945). Menurut Jimly Asshiddiqie, pembentukan Mahkamah Konstitusi dilakukan agar menjamin konstitusi sebagai hukum tertinggi dapat dijalankan seperti yang diharapakan. ${ }^{1}$ Oleh sebab itu, Mahkamah Konsitusi diberikan fungsi sebagai thr guardian of thr constttution. Fungsi utama Mahkamah Konstitusi di Indonesia pada hakekatnya merupakan pengawal agar konstitusi negara Indonesia dilaksanakn secara konsisten serta guna melakukan penafsiran tehradap konstitusi di Indonesia atau UUD NRI 1945 (thr interpreter of constttution). ${ }^{2}$ Fungsi tersebut dapat terlihat dari kewenangan yang dimiliki oleh Mahkamah Konstitusi sebagaimana termaktub dalam Pasal 24C ayat (1) dan ayat (2) UUD NRI 1945 yang berbunyi:

(1) Mahkamah Konstitusi berwenang mengadili pada tingkat pertama dan terakhir yang putusannya bersifat final untuk menguji undang-undang terhadap Undang-Undang Dasar, memutus sengketa kewenangan lembaga negara yang kewenangannya diberikan oleh Undang-Undang Dasar, memutus pembubaran partai politik dan memutus perselisihan tentang hasil pemilihan umum.

1) Asri Muhammad Saleh dan Wira Atma Hajri, Perihal Pengujian Peraturan Pemerintah Pengganti Undang-Undang, (Yogyakarta: Deepublish, 2018), hlm. 25.

2) Nomensen Sinamo, Hukum Tata Negara Suatu Kajian Kritis tentang Kelembagaan Negara, (Jakarta: Permata Aksara, 2012), hlm. 89. 
(2) Mahkamah Konstitusi wajib memberikan putusan atas pendapat Dewan Perwakilan Rakyat mengenai dugaan pelanggaran oleh Presiden dan/atau Wakil Presiden menurut Undang-Undang Dasar.

Secara khusus, kewenangan Mahkamah Konstitusi di atas diatur kembali dalam Pasal 10 Undang-Undang Nomor 24 Tahun 2003 tentang Mahkamah Konstitusi.

Berdasarkan ketentuan tersebut, dapat diketahui bahwa konstitusi telah memberikan landasan hukum bagi Mahkamah Konstitusi guna mengadili sengketa perselisihan tentang hasil pemilihan umum (yang selanjutnya disebut dengan Pemilu) di Indonesia. Namun permasalahannya adalah apabila undangundang tidak terdapat kejelasan tentang apa yang dimaksud dengan pengertian pemilu tersebut sebagai pelaksanaan lebih lanjut dari UUD NRI 1945, dan juga tidak ada kejelasan tentang ruang lingkup pemilu yang dimaksud, apakah hanya untuk pemilu sebagaimana dimaksud dalam Pasal 22E ayat (2) UUD NRI 1945 yakni pemilu untuk memilih anggota Dewan Perwakilan Rakyat, Dewan Perwakilan Daerah, Presiden dan Wakil Presiden, dan Dewan Perwakilan Rakyat Daerah atau pula termasuk di dalamnya Pemilihan Kepala Daerah (yang selanjutnya disebut dengan Pemilukada).

Sesuai dengan Pasal 22E ayat (2) UUD NRI 1945, maka dengan sendirinya perselisihan hasil Pemilu meluputi macam-macm Pemilu tersebut, yaitu Pemilu anggota Dewan Perwakilan Rakyat Daerah dan Dewan Perwakilan Rakyat, Pemilu anggota Dewan Perwakilan Daerah, serta Pemilu Presiden dan Wakil Presiden sebagaimana diatur pula dalam Pasal 74 ayat (2) Undang-Undang Nomor 48 Tahun 2009 tentang Kekuasaan Kehakiman. ${ }^{3}$ Sementara pengaturan dalam Pasal 24C dan Pasal 22E UUD NRI 1945 telah ditetapkan secara limitatif

3) Tim Penyusun Hukum Acara Mahkamah Konstitusi, Hukum Acara Mahkamah Konstitusi, (Jakarta: Sekretariat Jenderal dan Kepaniteraan Mahkamah Konstitusi Republik Indonesia, 2010), hlm. 223. 
bahwa kewenangan yang dipegang oleh Mahkamah Konstitusi terkait perselisihan tentang hasil pemilihan umum hanya terbatas yang telah diatur.

Namun dalam praktik pelaksanaannya perselisihan tentang hasil pemilihan umum mengalami perluasan, yang meliputi juga perselisihan tentang hasil pemilukada, sejak terjadinya pengalihan kewenangan mengadili yang semula berada pada Mahkamah Agung, kemudian beralih menjadi kewenangan Mahkamah Konstitusi berdasarkan Pasal 236C Undang-Undang Nomor 12 Tahun 2008 jo. Undang-Undang Nomor 32 Tahun 2004 tentang Pemerintah Daerah. Sedangkan, jika mengacu ke Pasal 24C UUD NRI 1945, maka kewenangan yang dipegang oleh Mahkamah Konstitusi hanya terkait penyelesaian perkara perselisihan mengenai hasil dari pemilihan umum saja.

Kewenamgan Mahkamah Konstitusi dalam mengadili perselisihan tentang hasil pemilukada ini merupakan kewenangan tambahan yang berasal dari undang-undang, di luar kewenangan pokok yang termaktub dalam Pasal 24C ayat (1) serta ayat (2) UUD NRI 1945. ${ }^{4}$ Penambahan kewenangan Mahkamah Konstitusi tersebut diawali oleh beberapa hal, antara lain adanya dasar pertimbangan hakim dalam Putusan Mahkamah Konstitusi Nomor 072073/PUU-II/2004 mengenai pengujian terhadap Undang-Undang Nomor 32 Tahun 2004 tentang Pemerintahan Daerah, dalam pertimbangan hukum hakim, Mahkamah Konstitusi dikatakan pembentuk undang-undang dimungkinkan secara konstitusional untuk menyatakan bahwa pengertian dari pemllkada yang dilaksanakan secara langsung saat ini merupakan bagian dari pemilu yang dimaksud dalam konstitusi. Drngan demikian, perselisihan mengenai hasil pemilukada menadi bagian dari kewenangan yang dipegang Mahkamah Konstitusi berdasarkan konstitusi.

Namun demikian, berkenaan drngan kewenangan tambahan Mahkamah Konstitusi untuk mengadili perselisihan tentang hasil pemilukada, yang

4) Ibid., hlm. 194. 
bersumber dari undang-undang, dapat dipersoalkan secara konstitusional atau asas hukum pada umumnya. ${ }^{5} \mathrm{Hal}$ ini didasari atas pendapat Bagir Manan yang menyatakan bahwa Pasal 24C ayat (1) dan ayat (2) UUD NRI 1945 mengatur secara expressis verbis, enumerative (limitatif) kewenangan yang dimiliki oleh mahkamah Konsitusi, sehingga tidak dapat ditafsirkan, apalagi ditambah, kecuali oleh peraturan yang berderajat sama. Selain itu, karena kewenangan yang dimiliki oleh Mahkamah Konstitusi diatur secara expressis verbis, enumerative (limitatif) di dalam UUD NRI 1945, maka kewenangan tersebut berkedudukan dan bersifat konstitusional. ${ }^{6}$ Sehingga menurut Jimly Asshiddiqie, ditinjau dari ajaran penafsiran atau ajaran konstitusi, penambahan kewenangan yang dipegang oleh Mahkamah Konstitusi harus diatur dalam UUD NRI 1945, bukan dengan undang-undang. ${ }^{7}$

Kemudian berdasarkan Putusan Mahkamah Kosntitusi Nomor 97/PUUXI/2013, Mahkamah Konstitusi berpendapat bahwa Pasal 236C UndangUndang Nomor 12 Tahun 2008 bersifat inkonstitusional, dikarenakan Pemilukada tidaklah termasuk dalam rezim Pemilu dan Mahkamah Konstitusi menghapus kewenangan tambahan untuk mengadili perselisihan hasil pemilukada di luar kewenangan yang termaktub dalam Pasal 24C ayat (1) dan ayat (2) UUD NRI $1945 .{ }^{8}$ Padahal di dalam putusan terdahulu yaitu Putusan No. 072-073/PUU-II/2004, Mahkamah Konstitusi justru menyatakan bahwa Mahkamah Konstitusi berwenang untuk mengadili sengketa pemilukada. Sehingga terdapat dua putusan yang saling bertentangan, oleh karena itu perlu dan patut dipertanyakan, yang mana yang benar dari kedua putusan tersebut.

5) Heru Widodo, Hukum Acara Sengketa Pemilukada: Dinamika di Mahkamah Konstitusi, (Jakarta: Konstitusi Press, 2018), hlm. 196.

6) Ibid.

7) Jimly Asshiddiqie et al, Putusan Monumental, Menjawab Problematika Kenegaraan, (Malang: Kerja Sama Setara Press dengan Forum Kajian Yurisprudensi, 2016).

8) Agus Sahbani, "MK Hapus Kewenangan Sengekata Pemilukada”, 19 Mei 2014, http://www.hukumonline.com/berita//baca/lt5379f071d5173/mk-hapus-kewenangan-sengketa-pemilukada,diakses, diakses pada tanggal 3 Agustus 2018, pukul 17.44 WIB. 
Bertitik tolak dari uraian tersebut, maka Penulis berminat untuk melakukan kajian melalui suatu penelitian secara mendalam khususnya tentang kewenangan Mahkamah Konstitusi dalam mengadili sengketa perselisihan hasil pemilukada. Penulisan ini berjudul: "Kewenangan Mahkamah Konstitusi dalam Mengadili Perkara Perselisihan Hasil Pemilihan Kepala Daerah (Suatu Kajian Terhadap Putusan Mahkamah Konstitusi Nomor 97/PUUXI/2013 jo. Putusan Mahkamah Konstitusi Nomor 072-073/PUU-II/2004)”.

\section{B. Perumusan Masalah}

Bertitik tolak pada latar belakang pada subbab A, maka pokok permasalahan yang diangkat dalam penulisan ini adalah:

1. Apakah pemilihan kepala daerah termasuk dalam rezim pemilihan umum sebagaimana dimaksud dalam Pasal 22E Undang-Undang Dasar Negara Republik Indonesia Tahun 1945 atau rezim pemerintahan daerah?

2. Apakah Mahkamah Konstitusi berwenang dalam mengadili perkara perselisihan hasil pemilihan kepala daerah berdasarakan Undang-Undang Dasar Negara Republik Indonesia Tahun 1945 serta Peraturan Perundangundangan?

\section{Metode Penelitian}

Metode penelitian yang dipergunakan yakni penelitian normatif, karena dalam penelitian ini digunakan sumber data penelitian berupa bahan-bahan kepustakaan atau yang disebut dengan Library research, yakni metode penelitian yang mengumpulkan data dari beberapa literatur. ${ }^{9}$ Selain bahan hukum primer dan sekunder, Penulis juga menggunakan bahan nonhukum. Pendekatan akan lebih ditujukan kepada pendekatan perundang-undangan dan pendekatan historis. Spesifikasi penelitian ini adalah penelitian deskriptif

9) Bambang Sunggono, Metode Penelitian Hukum, (Jakarta: PT Raja Grafindo Persada, 2007), hlm. 133 . 
analitis. Dengan penelitian yang bersifat deskriptif analitis, akan dapat dideskripsikan dan memberikan data seteliti mungkin mengenai objek yang diteliti. Teknik analisis data yang dipergunakan dalam penelitian adalah analisis data melalui cara deduktif.

\section{PEMBAHASAN}

\section{A. Rezim Pemilihan Kepala Daerah}

Pemilukada merupakan suatu pemilihan untuk memilih Kepala Daerah baik sebagai Gubernur, Bupati atau Walikota beserta wakilnya, masing-masing selaku kepala pemrrintahan darrah di tingkat provinsi dan kabupatrn/kota. Pasal 18 ayat (4) Undang-Undang Dasar Negara Republik Indonesia Tahun 1945 (yang selanjutnya disebut dengan UUD NRI 1945) menyatakan bahwa Gubernur, Bupati, dan Walikota masing-masing sebagai kepala pemerintah daerah provinsi, kabupaten dan kota dipilih secara demokratis. Dengan demikian dapat diartikan bahwa konstitusi negara Indonesia mengamanatkan agar pemilukada dilaksanakan secara demokratis.

Berdasarkan data hasil wawancara dengan Ahli Hukum Tata Negara, Ahmad Redi yang merupakan dosen Fakultas Hukum Universitas Tarumanagara, frasa "dipilih secara demokratis" yang tertuang dalam Pasal 18 ayat (4) UUD NRI 1945 dapat diartikan bahwa pemilukada dapat dilaksanakan melalui beberapa cara, yaitu dengan cara demokrasi langsung, yakni dengan dipilih langsung oleh rakyat atau demokrasi perwakilan, yakni dengan dipilih oleh Dewan Perwakilan Rakyat Daerah sebagai bentuk perwakilan rakyat. Selain itu, menurut Mahkamah Konstitusi dalam Putusan Nomor 072073/PUU-II/2004, frasa “dipilih secara demokratis" dalam Pasal 18 ayat (4) UUD NRI 1945 dapat juga diartikan bahwa pemilukada dapat juga dilakukan melalui cara-cara lain, selain menggunakan demokrasi langsung ataupun demokrasi perwakilan, sepanjang cara tersebut mencerminkan sifat demokratis. Hal ini sesuai dengan original intent Pasal 18 ayat (4) UUD NRI 1945 
yang dapat dilihat dari pembahasan pada Perubahan Kedua UUD NRI 1945, di mana Tim Perumus Perubahan UUD NRI 1945 menetapkan adanya frasa “dipilih secara demokratis" untuk membuka peluang agar pemilukada dapat dilaksanakan secara langsung dipilih oleh rakyat atau secara tidak langsung dipilih oleh perwakilan rakyat, yakni Dewan Perwakilan Rakyat Daerah. ${ }^{10}$ Berdasarkan keterangan dari Prof. Maria Farida Indrati yang merupakan salah satu pakar hukum yang hadir dalam pembahasan Perubahan Kedua UUD NRI 1945, pemilukada didesain untuk dipilih secara demokratis yang memiliki beragam mekanisme agar pemilukada di Indonesia dapat beragam mengikuti budaya yang terdapat di daerah pemilihan masing-masing, sehingga dapat diperoleh suatu mekanisme yang demokratis dan diterima oleh masyarakat sekitar.

Terkait mekanisme yang kemudian dipilih dalam pelaksanaan pemilukada ini akan menentukan apakah sebenarnya pemilukada termasuk dalam rezim pemilihan umum (pemilu) berdasarkan Pasal 22E UUD NRI 1945 ataukah rezim pemerintahan daerah. Cara yang dapat dilakukan untuk dapat memahami lebih mendalam terkait frasa "dipilih secara demokratis" yang terdapat dalam ketentuan Pasal 18 ayat (4) UUD NRI 1945, adalah dengan melakukan suatu penafsiran guna mengetahui makna yang terkandung di dalam ketentuan tersebut. Hal ini dikarenakan bahwa untuk mengetahui makna yang terkandung dari ketentuan yang terdapat dalam konstitusi, dikarenakan untuk mengetahui makna ketentuan tersebut tidak bisa dilakukan hanya dengan membaca ketentuan yang tertuang secara tertulis dalam konstitusi, sebab konstitusi negara Indonesia bersifat umum-abstrak.

Berdasarkan penafsiran sistematis, menafsirkan suatu ketentuan peraturan perundang-undangan dapat dilakukan dengan mencari hubungan antara

10) Tim Prnyusun Naskah Komprrhensif Prosrs dan Hasil Prrubahan UD NRI 1945, Naskah Komprrhensif Prrubahan Undang-Undang Dasar Negara Republik Indonesia Tahun 1945, Latar Belakang, Proses, dan Hasil Pembahasan, 1999-2002, Buku IV Kekuasaan Pemerintahan Negara Jllid 2, (Jakarta: Sekretariat Jenderal dan Kepaniteraan Mahkamah Konstitusi, 2010), hlm. 1211-1397. 
sebagian dari peraturan prrundang-undangan dengan peraturan prrundangundangan itu sendiri. ${ }^{11}$ Sehingga dalam ini, perlu dilihat pengaturan-pengaturan mengenai pemilukada maupun pemilu di dalam UUD NRI 1945 maupun di peraturan perundang-undangan lainnya.

Sebagaimana yang dikemukakan sebelumnya ketentuan mengenai pemilukada dapat dilihat secara tersirat dalam Pasal 18 ayat (4) UUD NRI 1945 yang menyatakan bahwa Gubernur, Bupati dan Walikota masing-masing sebagai kepala pemerintah daerah di tingkat provinsi, dan kabupaten/kota dipilih secara demokratis. Dalam hal ini terlihat bahwa pemilukada diatur sebagai bagian dari ketentuan BAB VI tentang Pemerintahan Daerah.

Sedangkan mengenai pemilu kita dapat melihatnya diatur terpisah dari pemilukada dalam Bab khusus pada UUD NRI 1945, yakni Bab VIIB tentang Pemilihan Umum, tepatnya dalam Pasal 22E UUD NRI 1945. Pasal 22E ayat (1) UUD NRI 1945 menjatakan bahwa "Pemilihan umum dilaksanakan secara langsung, umum, bebas, rahasia, jujur dan adil setiap lima tahun sekali." Lebih lanjut pada ayat (2) dinjatakan bahwa "Pemilihan umum diselenggarakan untuk memilih anggota Dewan Perwakilan Rakyat, Dewan Perwakilan Daerah, Presiden dan Wakil Presiden dan Dewan Perwakilan Rakyat Daerah.” Dengan demikian, kita dapat melihat bahwa yang dimaksud oleh pemilu dalam UUD NRI 1945 adalah pemilu yang dilakukan sebanyak satu kali dalam kurun waktu lima tahun dalam rangka memilih Presiden dan Wakil Presiden, Dewan Perwakilan Rakyat, Dewan Perwakilan Daerah, dan Dewan Perwakilan Rakyat Daerah dengan jujur, adil, bebas, rahasia, langsung dan umum.

Memperhatikan adanya pemisahan antara pengaturan pemilukada dengan pemilu dalam Pasal terpisah dan Bab yang terpisah di dalam UUD NRI 1945,

11) P.A.F. Lamintang dan C. Djisman Samosir, Delik-Drlik Khusus Kejahatan yang Ditujukan Terhadap Hak Milik dan Lain-Lain Hak yang Timbul dari Hak Milik, (Bandung: TARSITO Bandung, 2010), hlm. 3 
maka dapat terlihat bahwa pembentuk perubahan UUD NRI 1945 tidak bermaksud mengkategorikan pemilukada ke dalam Pemilu. Kalaupun terdapat pendapat sebaliknya, apabila meninjau secara historis, pembentukan Pasal 18 ayat (4) dalam UUD NRI 1945 telah dilaksanakan sejak perubahan kedua UUD NRI 1945 pada tahun 2000, sedangkan Bab VIIB mengenai Pemilihan Umum, terutama Pasal 22E UUD NRI 1945 baru terbentuk pada saat dilakukan perubahan ketiga UUD NRI 1945, dari sini terlihat bahwa apabila benar pembentuk perubahan UUD NRI 1945 bemaksud untuk mengkategorikan pemilukada ke dalam pemilu, maka tentunya pada saat perubahan ketiga UUD NRI 1945, ketentuan mengenai pemilukada juga diatur dalam Pasal 22E UUD NRI 1945 atau termasuk ke dalam Bab VIIB tentang Pemilihan Umum. Selain itu juga apabila merujuk pada pembahasan Perubahan Kedua UUD NRI 1945, Prof. Maria Farida Indrati menyatakan bahwa pemilukada memang tidak didesain untuk masuk ke dalam rezim pemilu sebagaimana dimaksud dalam Pasal 22E UUD NRI 1945.

Lebih lanjut, dengan merujuk pada pertimbangan hukum hakim dalam Putusan Mahkamah Konstitusi Nomor 072-073/PUU-II/2004, Mahkamah Konstitusi berpendapat bahwa pembentuk undang-undang memiliki open legal policy untuk mengatur atau menetapkan bahwa pemilukada termasuk dalam rezim pemilu atau dalam rezim pemerintahan daerah, yang terlihat dari original intent Pasal 18 ayat (4) UUD NRI 1945, di mana pada saat pembahasan pada masa perubahan ketiga, Patriali Akbar dari Fraksi Reformasi dan Katin Subyantoro dari Fraksi PDIP yang memberikan catatan atas usulan ahli bahwa pemilukada yang telah diatur di dalam Pasal 18 ayat (4) UUD NRI 1945 cukup diserahkan sepenuhnya kepada mekanisme yang ada di daerah, dan tidak perlu diatur secara tersendiri di dalam Pasal 22E UUD NRI 1945, karena berbeda dengan pemilu Presiden yang mau dilaksanakan secara langsung sehinga perlu 
ditambahkan dalam ketentuan mengenai Pemilu juga memilih Presiden dan Wakil Presiden, tetapi untuk Kepala Daerah tidak perlu. ${ }^{12}$

Dengan demikian berdasarkan peraturan perundang-undangan di Indonesia, dapat dilihat bahwa pembentuk undang-undang mengatur peraturan mengenai pemilukada dengan pemilu dalam peraturan perundang-undangan yang terpisah dan masing-masing berdiri sendiri, yakni Undang-Undang Nomor 10 Tahun 2016 jo. Undang-Undang Nomor 8 Tahun 2015 jo. Undang-Undang Nomor 1 Tahun 2015 tentang Penetapan Peraturan Pemerintah Pengganti UndangUndang Nomor 1 Tahun 2014 tentang Pemilihan Gubernur, Bupati dan Walikota Menjadi Undang-Undang yang mengatur secara khusus pemilukada, serta Undang- Undang Nomor 7 Tahun 2017 tentang Pemilihan Umum yang mengatur secara khusus mengenai pemilu untuk memilih anggota Dewan Perwakilan Rakyat, anggota Dewan Perwakilan Daerah, Presiden dan Wakil Presiden, dan anggota Dewan Perwakilan Rakyat Daerah.

Oleh sebab itu, Prnulis sependapat dengan pendapat Bapak Muhidin, yang menyatakan bahwa pemilukada saat ini tidak lagi berada dalam rezim pemilu pada tahun 2007 ketika pemilukada dan pemilu diatur dalam satu peraturan perundang-undangan yang sama, yaitu Undang-Undang Nomor 22 Tahun 2007 tentang Penyelenggara Pemilihan Umum, dan melainkan pemilukada saat ini kembali ke rezim pemerintahan daerah seperti pada tahun sebelum dibentuk Undang-Undang Nomor 22 Tahun 2007 tentang Penyelenggara Pemilihan Umum.

\section{B. Kewenangan Mahkamah Konstitusi dalam Mengadili Perkara Perselisihan Hasil Pemilihan Kepala Daerah}

12) Tim Penyusun Naskah Komprehensif Proses dan Hasil Perubahan UD NRI 1945, Naskah Komprehensif Perubahan Undang-Undang Dasar Negara Republik Indonesia Tahun 1945, Latar Belakang, Proses, dan Hasil Pembahasan, 1999-2002, Buku V Pemilihan Umum, (Jakarta: Sekretariat Jenderal dan Kepaniteraan Mahkamah Konstitusi, 2010), hlm. 572-574. 
Mahkamah Konstitusi adalah salah satu lembaga peradilan yang melaksanakan kekuasaan kehakiman, di samping Mahkamah Agung, yang dibentuk melalui Perubahan Ketiga Undang-Undang Dasar Negara Republik Indonesia Tahun 1945 (UUD NRI 1945) di tahun 2001. ${ }^{13}$ Mahkamah Konstitusi adalah lembaga negara yang terdapat dalam sistem ketatanegaraan Indonesia yang diberikan kewenangan dan kewajiban secara konstitusional dalam Pasal 24C ayat (1) dan ayat (2) UUD NRI 1945, yang meliputi:

1. Kewenangan untuk menguji undang-undang terhadap UUD NRI 1945;

2. Kewenangan untuk memutus sengketa kewenangan lembaga negara yang kewenangannnya diberikan oleh UUD NRI 1945;

3. Kewenangan untuk memutus pembubaran partai politik;

4. Kewenangan untuk memutus perselisihan tentang hasil pemilihan umum; dan

5. Kewajiban untuk memberikan putusan atas pendapat Drwan Perwakilan Rakyat mengenai dugaan pelanggaran oleh Presiden dan/atau Wakil Presiden menurut UUD NRI 1945.

Berdasarkan ketentuan tersebut, maka terlihat bahwa kewenangan yang dipegang oleh Mahkamah Konstitusi telah diatur secara limitatif dalam konstitusi negara Indonesia.

Dalam Pasal 22E ayat (2) UUD NRI 1945 ditegaskan bahwa pemilihan umum (yang selanjutnya disebut dengan Pemilu) dilaksanakan dalam rangka memilih anggota Dewan Perwakilan Rakyat, anggota Dewan Perwakilan Daerah, Presiden dan Wakil Presiden, serta anggota Dewan Perwakilan Rakyat Daerah. Oleh karenanya, di dalam Undang-Undang Nomor 23 Tahun 2004 tentang Mahkamah Konstitusi (Undang-Undang Nomor 23 Tahun 2004) pun ditegaskan bahwa yang dimaksud dengan pemilu dalam hal kewenangan Mahkamah Konstitusi dalam mengadili perkara perselisihan hasil pemilu

13) Muhammad Yamin, Naskah Persiapan Undang-Undang Dasar 1945, Jilid I, (Jakarta: Yayasan Prapanca, 1959), hlm. 341-342. 
adalah pemilu legislatif dan pemilu presiden. Hal ini terlihat dalam Pasal 74 ayat (1) Undang-Undang Nomor 23 Tahun 2004 yang menyatakan bahwa siapa saja yang dapat menjadi Pemohon dalam pengajuan permohonan perkara perselisihan hasil pemilu, adalah Perorangan Warga Negara Indonesia calon anggota Dewan Daerah Peserta Pemilu,.Pasangan calon Presiden dan Wakil Presiden Peserta Pemilu, dan Partai Politik Peserta Pemilu. Dengan demikian dapat dismpulkan bahwa pemilu yang dimaksud dalam kewenangan yang dipegang oleh Mahkamah Konstitusi adalah pemilu untuk memilih anggota Dewan Perwakilan Rakyat, anggota Dewan Perwakilan Daerah, Presiden dan Wakil Presiden, serta anggota Dewan Perwakilan Rakyat Daerah.

Namun dalam perkembangannya, kewenangan Mahkamah Konstitusi mengalami perkembangan atau perubahan yang terjadi secara cepat. ${ }^{14}$ Perkembangan tersebut terlihat dari adanya penambahan kewenangan yang dipegang oleh Mahkamah Konstitusi dalam hal menyelesaikan perkara mengenai persrlisihan tentang hasil pemilihan kepala daerah (yang selanjutnya disebut dengan Pemilukada) di luar dari kewenangan pokok yang diberikan oleh Pasal 24C ayat (1) dan ayat (2) UUD NRI 1945. ${ }^{15}$

Semula, kewenangan tambahan yang dipegang oleh Mahkamah Konstitusi ini dimiliki oleh Mahkamah Agung, di mana perkara mengenai perselisihan hasil pemilihan Gubernur diselesaikan di Mahkamah Agung, dan mengenai persrlisihan hasil pemilihan Bupati dan Walikota diselesaikan oleh Pengadilann Tinggi berdasarkan kewenangan delegasi dari Mahkamah Agung, berdasarkan Pasal 106 Undang-Undang Nomor 32 Tahun 2004 tentang Pemerintahan Daerah. Kewenangan tersebut baru berpindah sejak diundangkannya UndangUndang Nomor 12 Tahun 2008 jo. Undang-Undang Nomor 32 Tahun 2004 tentang Pemerintahan Daerah, di mana dalam Pasal 236C disebutkan bahwa

14) Maruarar Siahaan, Hukum Acara Mahkamah Konstitusi, Edisi 2, (Jakarta: Sinar Grafika, 2011), hlm. 165-166.

15) Heru Widodo, Hukum Acara Sengketa Pemilukada: Dinamika di Mahkamah Konstitusi, (Jakarta: Konstitusi Press, 2018), hlm. 194. 
penanganan perkara perselisihan hasil pemilukada yang dimiliki oleh Mahkamah Agung dipindahkan kepada Mahkamah Konstitusi dalam jangka waktu 18 bulan sejak diundangkannya Undang-Undang ini.

Lahirnya Pasal 236C Undang-Undang Nomor 12 Tahun 2008 ini dilatarbelakangi dengan adanya Putusan Mahkamah Konstitusi No. 97/PUUII/2004 terkait pengujian materiil Undang-Undang Nomor 32 Tahun 2004 yang di dalam pertimbangan hukum hakim terkait permohonan yang diajukan oleh Para Pemohon agar menyatakan bahwa Pasal 106 ayat (1) sampai dengan ayat (7) Undang-Undang Nomor 32 Tahun 2004 bersifat inkonstitusional, Mahkamah Konstitusi kemudian megnatakan bahwa dalam hal ini pembentuk undang-undang secara konstitusional dapat menyatakan bahwa pemilukada yang dilaksanakan dengan cara dipilih secara langsung oleh rakyat atau pemilukada langsung merupakan perluasan dari pengertian pemilihan umum (yang selanjutnya disebut dengan Pemilu) berdasarkan Pasal 22E UUD NRI 1945, dengan demikian pemilukada masuk ke dalam rezim pemilu. Dengan demikian, secara mutatis mutandis penyelesaian perkara perselisihan hasil pemilukada menjadi kewenangan Mahkamah Konstitusi berdasarkan ketentuan Pasal 24C ayat (1) UUD NRI 1945. Namun, dalam hal ini pembentuk undangundang juga dapat menyatakan bahwa pemilukada langsung itu bukanlah pemilu sebagaimana dimaksud dalam Pasal 22E UUD NRI 1945, sehingga penyelesaian perkara perselisihan hasil pemilukada bukan merupakan kewenangan Mahkamah Konstitusi, melainkan kewenangan tambahan yang dimiliki oleh Mahkamah Agung sebagaimana dimungkinkan berdasarkan Pasal 24C ayat (1) UUD NRI 1945 yang menentukan bahwa Mahkamah Konstitusi memegang kewenangan lain yang diatur dalam undang-undang. Lebih lanjut di dalam pertimbangan Putusan Mahkamah Konstitusi Nomor 072-073/PUUII/2004, Makhamah Konstitusi berpendapat bahwa rezim pemilukada langsung, walaupun dinyatakan oleh pembentuk undang-undang btidak termasuk rezim pemilu, namun pemilukada tetap merupakan pemilu yang mana 
penyelenggaraannya harus memenuhi asas-asas pemilu yang diatur dalam konstitusi.

Oleh karena itu, pembentuk undang-undang menganggapi Putusann Mahkamah Konstitusi No. 072-073/PUU-II/2004 dengan mengeluarkan Undang- Undang Nomor 22 Tahun 2007 tentang Penyelenggara Pemilihan Umum, yang menegaskan bahwa pemilukada adalah Pemilu dalam rangka memilih krpala darrah berserta wakilnya yang dilaksanakan secara langsung berdasarkan Pancasila dan UUD NRI 1945. Sehingga pemilukada menjadi bagian dalam lingkup pemilu yang memiliki asas-asas penyelenggaraan dan lembaga penyelenggara yang sama dengan pemilu srbagaimana tersurat dalam Pasal 22E UUD NRI 1945. Atas dasar hal tersebut, Mahkamah Konstitusi menjadi berwenang untuk mengadili perkara perselisihan hasil pemilukada.

Lebih lanjut di dalam Penjelasan Umum paragraf kelima Undang-Undang Nomor 22 Tahun 2007, terdapat perubahan penting di mana pengaturan lembaga penyelenggara pemilu, Dewan Perwakilan Daerah, Dewan Perwakilan Rakyat dan Dewan Perwakilan Rakyat Daerah; pemilu Presiden dan Wakil Presiden; serta pemilukada yang diatur dalam beragam peraturan perundangundangan, kemudian semua peraturan trrsebut disatukan dan disrmpurnakan ke dalam suatu regulasi yang secara komprrhensif. Sehingga pengisian jabatan kepala daerah secara langsung yang semula menjadi bagian dari sistem otonomi daerah bergeser menjadi bagian dari sistem pemilu yang penyelenggaraannya sama-sama di bawah koordinasi dari Komisi Pemilihan Umum secara nasional. $^{16}$

Lebih lanjut pembentuk undang-undang juga membentuk Undang-Undang Nomor 48 Tahun 2009 tentang Kekuasaan Kehakiman, di mana dalam Pasal 29 ayat (1) menegaskan bahwa Mahkamah Konstitusi dapat memegang kewrnangan lain yang diatur dalam undang-undang. Makna krwenangan lain

16) Heru Widodo, Op.Cit., hlm. 87. 
disini berdasarkan penjelasan Pasal 29 ayat (1) Undang-Undang Nomor 48 Tahun 2009 adalah kewenangan untuk menyelesaikan sengketa hasil pemilukada berdasarkan dengan ketentuan peraturan perundang-undangan. Sehingga dalam hal ini, pembentuk undang-unda gmenegaskan diperbolehkannya penambahan kewenangan yang dipegang oleh Mahkamah Konstitusi yang telah diatur sebelumnya di dalam Pasal 236C Undang-Undang Nomor 12 Tahun 2008.

Menganggapi ketentuan Pasal 236C Undang-Undang Nomor 12 Tahun 2008 tersebut, Ketua Mahkamah Agung berserta Ketua Mahkamah Konstitusi melakukan pengalihan kewenangan untuk memutus sengketa perselisihan hasil pemilukada secara resmi pada tanggal 29 Oktober 2008 dengan menandatangani Nota Kesepahaman antara Mahkamah Agung dan Mahkamah Konstitusi. ${ }^{17}$ Sejak saat itulah, untuk pertama kalinya kewenangan tambahan untuk memutus perselisihan tentang hasil pemilukada diberikan kepada Mahkamah Konstitusi.

Penambahan kewenangan yang dipegangoleh Mahkamah Konstitusi untuk menyelesaikan perkara perselisihan hasil pemilukada ini tentunya menimbulkan polemik yang dapat dipermasalahkan secara konstitusional, dikarenakan sebagaimana telah disebutkan di atas bahwa ketentuan Pasal 24C ayat (1) UUD NRI 1945 diatur secara limitatif, sehingga tidak dapat adanya penambahan kewenangan melalui undang-undang. Hal ini juga diperkuat dengan pernyataan Harjono dari Fraksi PDIP dalam pembahasan perubahan ketiga UUD NRI 1945 yang menentukan bahwa krwenangan Mahkamah Konstitusi yang dirumuskan dalam Pasal 24C UUD NRI 1945 pasti terbatas, yaitu kewenangan mengadli perkara pada tingkat pertama dan terakhir yang putusanya bersifat final dalm rangka menyelesaikan sengketa pembubaran partai politik, menyelesaiakan sengketa kewenangan lembaga negara yang kewenangannya diberikan oleh

17) Ash, "MA Sambut Baik Sengketa Pilkada Balik ke MK", 18 Februari 2015, http://www.hukumonline.com/berita/baca/lt54e3fb84238ea/ma-sambut-baik-sengketa-pilkada-bali kke-mk, diakses pada tanggal 29 November 2018, pukul 18.09 WIB. 
UUD NRI 1945, pengujian undang-undang terhadap UUD NRI 194, dan menyelesaiaka sengketa perselisihan tentang hasil pemilihan umum. ${ }^{18}$ Sehingga, tidak mungkin dilakukan penambahan kewenangan kepada Mahkamah Konstitusi dengan undang-undang.

Pendapat serupa juga dikemukakan oleh Bagir Manan yang menyatakan bahwa Pasal 24C ayat (1) dan ayat (2) UUD NRI 1945 telah mengatur krwenangan yang dimiliki oleh Mahkamah Konstitusi sedemikan rupa secara expressis verbis, enumerative atau bersifat limitatif. ${ }^{19}$ Dengan demikian, sesuai dengan teori penafsiran, maka segala ketentuan yang diatur secara expressis verbis, enumerative atau limitatif tidak dapat ditafsirkan, apalagi ditambah, kecuali oleh peraturan yang berderajat sama. Lebih lanjut, dikarenakan krwenangan Mahkamah Konstitusi telah diatur secara limitatif dalam Pasal 24C ayat (1) dan ayat (2) UUD NRI 1945, maka berbagai kewenangan tersebut berkedudukan dan bersifat konstitusional, sehingga apabila mengacu pada teori penafsiran konstitusi, maka penambahan kewenangan Mahkamah Konstitusi seharusnya diatur dalam UUD NRI 1945, bukanlah dengan undang-undang. ${ }^{20}$

Alasan lain yang dapat menyebabkan bahwa kewenangan tamabhan Mahkamah Konstitusi guna meneyelesaikan perkara perselisihan tentang hasil pemilukada adalah adanya fakta bahwa konstitusi negara Indonesia, yakni UUD NRI 1945 telah mengatur secara terpisah pengaturan mengenai pemilukada dalam Pasal 18 ayat (4) UUD NRI 1945 dengan pemilu dalam Pasal 22E UUD NRI 1945. Secara sistematis, kita dapat melihat bahwa Pasal 22E ayat (1) UUD NRI 1945 telah menentukan secara trgas dan jelass bahwa pemilihan umum diselenggarakan secara langsung umum, bebas, rahasia, jujur, dan adil dalam

18) Tim Penyusun Naskah Komprehensif Proses dan Hasil Perubahan UD NRI 1945, Naskah Komprehensif Perubahan Undang-Undang Dasar Negara Republik Indonesia Tahun 1945, Latar Belakang, Proses, dan Hasil Pembahasan, 1999-2002, Buku VI Kekuasaan Kehakiman, (Jakarta: Sekretariat Jenderal dan Kepaniteraan Mahkamah Konstitusi, 2010), hlm. 572.

19) Heru Widodo, Op.Cit., hlm. 196.

20) Jimly Asshiddiqie et al, Putusan Monumental, Menjawab Problematika Kenegaraan, (Malang: Kerja sama Setara Press dengan Forum Kajian Yurisprudensi, 2016). 
kurun waktu lima tahun sekali, dan Pasal 22E ayat (2) UUD NRI 1945 menyatakan bahwa pemilihan umum dilaksanakan untuk memilih anggota Dewan Perwakilan Rakyat, anggota Dewan Perwakilan Daerah, Presiden dan Wakil Presiden, serta anggota Dewan Perwakilan Rakyat Daerah. Sehingga dapat dipahami bahwa pemilu yang dimaksud dalam UUD NRI 1945 adalah pemilu yang diselenggarakan sekali dalam kurun waktu lima tahun yang dilaksanakan secara bebas langsung, umum, rahasia, adil dan jujur ntuk memilih anggota Dewan Perwakilan Rakyat, anggota Dewan Perwakilan Daerah, Presiden dan Wakil Presiden, serta anggota Dewan Perwakilan Rakyat Daerah.

Sementara mengenai pemilihakn kepala daerah tersirat dicantumkan dalam Pasal 18 ayat (4) UUD NRI 1945 yang menyatakan bahwa Bupati, Walikota dan Gubernur masing-masing menjabat selaku kepala pemerintahan daerah provinsi, kabupaten dan kota secara drmokratis. Hal ini berarti bahwa Konstitusi negara Indonesia tidak mencampurkan antara pemilukada ke dalam BAB VIIB yang mengatur secara khusus mengenai pemilu. Sehinga dalam hal ini dapat dikatakan bahwa pemilukada tidak tergolong dalam rezim pemilu.

Padahal, untuk memasukkan kewenangan tambahan kepada Mahkamah Konstitusi untuk mengadili perkara perselisihan tentang hsil pemlukada ke dalam batang tubuh UUD NRI 1945 yang merupakan suatu konstitusi yang bersifat rigid, membutuhkan upaya yang besar dan terbilang sulit. Hal ini dikarenakan perubahan terhadap konstitusi rigid mensyaratkan tata cara khusus yang berbeda dengan perubahan terhadap undang-undang, sehingga secara konseptual, Bagir Manan berpendapat bahwa UUD NRI 1945 yang bersifat rigid dimaksudkan untuk mencegah terjadinya perubahan agar menjamin keajegan atau stabilitas penyelenggaraan negara di Indonesia. ${ }^{21}$ Sehingga dalam hal ini seharusnya Mahkamah Konstitusi tidak diberikan kewenangan tambahan

21) Bagir Manan dan Susi Dwi Harijanti, Memahami Makna Konstitusi: Makna Akualisasi dan Aktualisasi, (Jakarta: Raja Grafindo Persada, 2015), hlm. 94-101. 
di luar kewenangan pokok yang diberikan oleh Pasal 24C ayat (1) dan ayat (2) UUD NRI 1945.

Menganggapi problematik ini, terdapat beberapa Pemohon yang mengajukan permohonan pengujian materiil terhadap Undang-Undang Nomor 12 Tahun 2008 jo. Undang-Undang Nomor 32 Tahun 2004 tentng Pemerintahan Daerah dan Undang-Undang Nomor 48 Tahun 2009 tentang Kekuasaan Kehakiman terhadap UUD NRI 1945 dengan alasan bahwa pemilukada dalam konstitusi telah diaturs secara terpisah di dalam Pasal 18 ayat (4) UUD NRI 1945 dengan pengaturan mengenai pemilu dalam Pasal 22E UUD NRI 1945, sehingga dapat disimpulkan bahwa secara konstitusional pemilukada tidak termasuk dalam rezim pemilu, dengan demikian kewenangan Mahkamah Konstitusi dalam menyelesaiakan perselisihan tentang hasil pemilukada harus dinyatakan inkonstitusional.. Terhadap permohonan tersebut, Mahkamah Konstitusi menjatuhkan Putusan Mahkamah Konstitusi No. 97/PUU-XI/2013, di mana Mahkamah Konstitusi melakukan self restraint dengan menghapus kewenangan tambahan yang diaturr dalam Pasal 236C Undang-Undang Nomor 12 Tahun 2008 untuk memutus sengketa perselisihan tentang hasil pemilukada di luar kewenangan pokok yang diatur dalam Pasal 24C ayat (1) dan ayat (2) UUD NRI 1945 dengan mempertimbangkan original intent dari Pasal 24C ayat (1) UUD NRI 1945 yang telah mengatur kewenangan Mahkamah Konstitusi secara limitatif.

Walaupun Mahkamah Konstitusi telah mentatakan bahwa Mahkamah Konstitusi tidak berwenang untuk menyelesaikan sengketa perselisihan tentang hasil pemulukada, namun dengan mempertimbangkan kemungkinan timbulnya ketidakpastian hukum dan kekosongan hukum terkait kevakuman lembaga yang berwenang untuk menyelesaikan hasil pemilukada, maka penyelesaian perkara perselisihan hasil pemilukada tetap dilaksanakan oleh Mahkamah Konstitusi sampai adanya undang-undang yang menyatakan lain mengenai hal itu. 
Pasca Putusan Mahkamah Konstitusi No. 97/PUU-XI/2013, pembentuk undang-undang membentuk Undang-Undang Nomor 22 Tahun 2014 tentang Pemilihan Gubernur, Bupati, dan Walikota (yang selanjutnya disebut dengan Undang-Undang Nomor 22 Tahun 2014) dan menetapkan bahwa pemilukada dilaksanakan melalui Dewan Perwakilan Rakyat Daerah atau tidak langsugn. Perubahan mekanisme pemilukada tersebut menadapat reaaksi penolakan secara luas dari masyarakat, sehingga menganggapi reaksi tersebut, Presiden mencabut pemberlakukan Undang-Undang Nomor 22 Tahun 2014 terebut dengan Peraturan Pemerintah Pengganti Undag-Undang Nomor 1 Tahun 2014 tentag Pemilihan Gubernur, Bupati, dan Walikota, yang kemudian ditetapkan menjadi undang-undang dengan Undag-Undang Nomor 1 Tahun 2015 tentng Penetapan Peraturan Pemerintah Pengganti Undang-Undag Nomor 1 Tahun 2014 tentng Pemilihan Gubernur, Bupati, dan Walikota Menjadi Undang-Undang (yang selanjutnya disebut dengan Undang-Undang Nomor 1 Tahun 2015).

Undang-Undang Nomor 1 Tahun 2015 tersebut mengatur mengenai pemberian kewenangan kepada 4 Pengadilan Tinggi yang dipilih Mahkamah Agung untuk mengadili perkara perselisihan tentang hasil pemilukada, atas penyelenggaraan pemilukada secara serentak nasional, namun belum sempat diimplementasikan dalam pelaksanaan pemilukada, kewenangan tersebut dianulir juga dengan diundangkannya Undang-Undang Nomor 8 Tahun 2015 yang menyatakan kembali kewenangan dalam mengadili perkara perselisihan tentang hasil pemilukada diberikan kepada Mahkamah Konstitusi sebagai kewenangan transisional sampai adanya badan peradilan khusus untuk menyelesaikan sengketa pemilihan serentak dibentuk sebagaimana dimaksud dalam Pasal 157 ayat (3) Undang-Undang Nomor 8 Tahun 2015. Sampai saat ini, badan peradilan pemilu ini yang dikatakan akan dibuat sebelum pelaksanaan pemilihan nasional serentak belum direalisasikan, bahkan tidak ditegaskan apakah pengaturannya sebagai badan peradilan yang berdiri sendiri 
ataupun menjadi peradilan khusus di bawah lingkungan peradilan umum ataupun peradilan tata usaha negara. ${ }^{22}$

Padahal sebagaimana yang telah dikemukakan sebelumnya di dalam Putusan Mahkamah Konstitusi No. 97/PUU-XI/2013, Mahkamah Konstitusi telah menyatakan bahwa kewenangan yang dipegang Mahkamah Konstitusi untuk memutus perkara mengenai perselisihan tentang hasil pemilukada yang diberikan oleh undang-undang bertentangan dengan UUD NRI 1945. Walaupun Mahkamah Konstitusi menyatakan dirinya masih berwenang untuk mengadili perkara perselisihan hasil pemilukada tersebut, namun secara gramatikal kewenangan tamabahan tersebut hanya berlaku secara sah sampai pembentuk undang-undang membentuk suatu produk hukum berupa undang-undang yang mengatur mengenai kewenangan tersebut diberikan kepada siapa. Oleh karena itu, seharusnya sejak diundangkannya Undang-Undang Nomor 22 Tahun 2014 tentng Pemilihan Gubernur, Bupati dan Walikota yang menentukan bahwa perkara persrlisihan hasil pemilukada diselesaikan oleh 4 Pengadilan Tinggi yang ditunjuk oleh Mahkamah Agung, maka Mahkamah Konstitusi sudah terbebas dari kewenangan tambahan untuk menyelesaiakan perkara perselisihan hasil pemilukada dan tidak boleh diberikan kembali kewenangan tersebut hanya dengan menggunakan undang-undang sebagai landasan hukum, kecuali diberikan dengan kewenangan atribusi dari UUD NRI 1945.

Merujuk pada stufenbau theory yang digagas oleh Hans Kelsen, yang menyatakan bahwa norma hukum merupakan suatu kaidah yang berjenjangjenjang dan berlapis-lapis dalam hierarki norma hukum, di mana suatu norma yang rendah harus didasarkan pada norma yang tingkatanya lebih tinggi, dan norma yang tingakatannya lebih tinggi tersebut harus didasarkan pada norma yang lebih tinggi lagi, hingga akhrinya sampai pada suatu puncak norma atau

\footnotetext{
22) Heru Widodo, Op.Cit., hlm. 8.
} 
yang dinamakan norma dasar atau grund norm. ${ }^{23}$ Dengan demikian apabila kita merujuk pada hierarki peraturan perundang-undangan di Indonesia berdasarkan Pasal 7 ayat (1) Undang-Undang Nomor 12 Tahun 2011 tentng Pembentukan Peraturan Perundag-undangan, maka berdasarkan asas hukum "lex superiori derogate lex inferiori", undang-undang sebagai peraturan perundang-undangan yang berada di bawah UUD NRI 1945 harus memperhatikan UUD NRI 1945 yang merupakan aturan hukum yang lebih tinggi. Sehingga dengan mempertimbangkan kewenangan yang dimilki Mahkamah Konstitusi yang bersifat limitatif dalam ketentuan Pasal 24C UUD NRI 1945, maka Pasal 157 ayat (3) Undang-Undang Nomor 8 Tahun 2015 bersifat inkonstitusional, disebabkan Pasal 22E dan Pasal 24C UUD NRI 1945 yang merupakan suatu norma hukum yang lebih tinggi dibandingkan Undang-Undag Nomor 8 Tahun 2015 tidak menentukan adanya kewajiban kepada norma hukum yang lebih rendah darinya guna mengatur mengenai pemberian kewenangan kepada Mahkamah Konstitusi terkait penyelesaian perkara perselisihan hasil pemilukada.

Berdasarkan hal tersebut, Penulis sependapat dengan pendapat Bapak Muhidin, selaku Panitera Muda II Mahkamah Konstitusi bahwa kewenangan transisional yang dimiliki Mahkamah Konstitusi untuk memutus perkara perselisihan tentang hasil pemilukada dicabut dan segera dialihkan ke Mahkamah Agung atau badan peradilan khusus lainnya untuk memutus perselisihan tentang hasil pemilukada. Walaupun sebenarnya kewenangan transisional ini tidak diberikan tenggang waktu berlakunya, melainkan hanya tertulis sampai ada badan peradilan khusus untuk itu, sebaiknya segera dilaksanakan, karena kewenangan transisional ini menyebabkan kewenangan pokok Mahkamah Konstitusi menjadi tidak terselesaikan dengan cepat, karena harus menyelesaikan perkara perselisihan hasil pemilukada. hlm. 54.

23) Ni'matul Huda, UUD 1945 dan Gagasan Amandemen Ulang, (Jakarta: Rajawali Press, 2008), 


\section{PENUTUP}

\section{A. Kesimpulan}

Bertitik tolak dari analisis yang telah dilakukan, maka ditarik beberapa kesimpulan terkait permasalahan yang diangkat, yakni:

1. Pemilukada tidak dapat dikatakan termasuk dalam rezim pemilu, dikarenakan berdasarkan original intent Pasal 18 ayat (4) dan Pasal 22E UUD NRI 1945, pemilukada tidak didesain untuk masuk ke dalam rezim pemilu, dikarenakan para pakar hukum pada saat pembahasan Perubahan Kedua UUD NRI 1945, menginginkan adanya beragam mekanisme pemilukada yang disesuaikan dengan budaya masing-masing daerah, sehingga tidak harus secara langsung seperti pemilu dalam Pasal 22E UUD NRI 1945, tetapi secara demokratis, baik secara tidak langsung, maupun langsung.

2. Selain itu, Mahkamah Konstitusi tidak berwenang untuk memutus perkara perselisihan hasil pemilukada, dikarenakan pemilukada tidak termasuk dalam rezim pemilu berdasarkan Pasal 22E UUD NRI 1945, sehingga tidak termasuk dalam kewenangan Mahkamah Konstitusi sebagaimana dimaksud dalam Pasal 24C ayat (1) UUD NRI 1945. Lebih lanjut, penambahan kewenangan Mahkamah Konstitusi yang terjadi saat ini bersifat inkonstitusional mempertimbangkan bahwa Pasal 24C ayat (1) dan ayat (2) UUD NRI 1945 telah diatur secara limitatif, sehingga tidak dapat diubah maupun ditambah lagi oleh undang-undang.

\section{B. Saran}

Adapun saran dalam penelitian ini ditujukan kepada Pemerintah agar sebaiknya segera merealisasikan pembentukan badan peradilan khusus untuk memutus perkara perselisihan hasil pemilukada, sehingga kewenangan tambahan yang bersifat transisional yang dimiliki oleh Mahkamah Konstitusi 
dapat dihapuskan agar Mahkamah Konstitusi dapat fokus menjalankan kewenangan serta kewajiban pokok yang diamanatkan Konstitusi dalam Pasal 24C ayat (1) dan ayat (2) UUD NRI 1945.

\section{DAFTAR PUSTAKA}

\section{A. Buku}

Asshiddiqie, Jimly et al. Putusan Monumental, Menjawab Problematika Kenegaraan. Malang: Kerja Sama Setara Press dengan Forum Kajian Yurisprudensi, 2016.

Huda, Ni'matul. UUD 1945 dan Gagasan Amandemen Ulang. Jakarta: Rajawali Press, 2008.

Lamintang, P.A.F. dan C. Djisman Samosir. Delik-Delik Khusus Kejahatan yang Ditujukan Terhadap Hak Milik dan Lain-Lain Hak yang Timbul dari Hak Milik. Bandung: TARSITO Bandung, 2010.

Saleh, Asri Muhammad dan Wira Atma Hajri, Perihal Pengujian Peraturan Pemerintah Pengganti Undang-Undang. Yogyakarta: Deepublish, 2018.

Siahaan, Maruarar. Hukum Acara Mahkamah Konstitusi, Edisi 2. Jakarta: Sinar Grafika, 2011.

Sinamo, Nomensen. Hukum Tata Negara Suatu Kajian Kritis tentang Kelembagaan Negara. Jakarta: Permata Aksara, 2012.

Sunggono, Bambang. Metode Penelitian Hukum. Jakarta: PT Raja Grafindo Persada, 2007.

Tim Penyusun Hukum Acara Mahkamah Konstitusi. Hukum Acara Mahkamah Konstitusi. Jakarta: Sekretariat Jenderal dan Kepaniteraan Mahkamah Konstitusi Republik Indonesia, 2010.

Tim Penyusun Naskah Komprehensif Proses dan Hasil Perubahan UD NRI 1945. Naskah Komprehensif Perubahan Undang-Undang Dasar Negara Republik Indonesia Tahun 1945, Latar Belakang, Proses, dan Hasil Pembahasan, 1999-2002, Buku IV Kekuasaan Pemerintahan Negara Jilid 2. Jakarta: Sekretariat Jenderal dan Kepaniteraan Mahkamah Konstitusi, 2010.

Tim Penyusun Naskah Komprehensif Proses dan Hasil Perubahan UD NRI 1945. Naskah Komprehensif Perubahan Undang-Undang Dasar Negara Republik Indonesia Tahun 1945, Latar Belakang, Proses, dan Hasil Pembahasan, 1999-2002, Buku V Pemilihan Umum. Jakarta: Sekretariat Jenderal dan Kepaniteraan Mahkamah Konstitusi, 2010.

Tim Penyusun Naskah Komprehensif Proses dan Hasil Perubahan UD NRI 1945. Naskah Komprehensif Perubahan Undang-Undang Dasar Negara Republik Indonesia Tahun 1945, Latar Belakang, Proses, dan Hasil Pembahasan, 
1999-2002, Buku VI Kekuasaan Kehakiman. Jakarta: Sekretariat Jenderal dan Kepaniteraan Mahkamah Konstitusi, 2010.

Widodo, Heru. Hukum Acara Sengketa Pemilukada: Dinamika di Mahkamah Konstitusi. Jakarta: Konstitusi Press, 2018.

Yamin, Muhammad. Naskah Persiapan Undang-Undang Dasar 1945, Jilid I. Jakarta: Yayasan Prapanca, 1959.

\section{B. Peraturan Perundang-Undangan}

Indonesia. Undang-Undang Dasar Negara Republik Indonesia Tahun 1945. . Undang-Undang Nomor 24 Tahun 2003 tentang Mahkamah Konstitusi. . Undang-Undang Nomor 32 Tahun 2004 tentang Pemerintahan Daerah. . Undang-Undang Nomor 22 Tahun 2007 tentang Penyelenggara Pemilihan Umum.

. Undang-Undang Nomor 12 Tahun 2008 tentang Perubahan Atas UndangUndang Nomor 32 Tahun 2004 tentang Pemerintahan Daerah. . Undang-Undang Nomor 48 Tahun 2009 tentang Kekuasaan Kehakiman . Undang-Undang Nomor 8 Tahun 2011 tentang Perubahan Atas UndangUndang Nomor 24 Tahun 2003 tentang Mahkamah Konstitusi. . Undang-Undang Nomor 12 Tahun 2011 tentang Pembentukan Peraturan Perundang-Undangan.

- Undang-Undang Nomor 1 Tahun 2015 tentang Penetapan Peraturan Pemerintah Pengganti Undang-Undang Nomor 1 Tahun 2014 tentang Pemilihan Gubernur, Bupati dan Walikota Menjadi Undang-Undang.

. Undang-Undang Nomor 8 Tahun 2015 tentang Perubahan Atas UndangUndang Nomor 1 Tahun 2015 tentang Penetapan Peraturan Pemerintah Pengganti Undang-Undang Nomor 1 Tahun 2014 tentang Pemilihan Gubernur, Bupati dan Walikota Menjadi Undang-Undang.

. Peraturan Pemerintah Pengganti Undang-Undang Nomor 1 Tahun 2014 tentang Pemilihan Gubernur, Bupati dan Walikota.

Mahkamah Konstitusi. Putusan Mahkamah Konstitusi Nomor 072-073/PUU-II/2004. Putusan Mahkamah Konstitusi Nomor 97/PUU-XI/2013.

\section{Website}

Ash. "MA Sambut Baik Sengketa Pilkada Balik ke MK". http://www.hukumonline.com/berita/baca/lt54e3fb84238ea/ma-sambut-baiksengketa-pilkada-bali k-ke-mk, diakses pada tanggal 29 November 2018.

Sahbani, Agus. "MK Hapus Kewenangan Sengekata Pemilukada". http://www.hukumonline.com/berita/baca/lt5379f071d5173/mk-hapuskewenangan-sengketa-pemi lukada, diakses pada tanggal 3 Agustus 2018. 